\title{
NUTRITIONAL STATUS AND DIETARY INTAKE OF SEMAI INDIGENOUS CHILDREN BELOW FIVE YEARS IN PERAK, PENINSULAR MALAYSIA
}

\author{
Anto Cordelia, T.A.D. ${ }^{1}$, Sylvia Subapriya $\mathrm{M.}^{2}$ and Hnin $\mathrm{PA}^{1}$ \\ ${ }^{1}$ Department of Chemical Science, Faculty of Science, University Tunku Abdul Rahman (Perak Camus), 31900 Kampar, \\ Perak, Malaysia. \\ ${ }^{2}$ Department of Food Science and Nutrition, Faculty of Home Science, Avinashilingam Institute for Home Science and \\ Higher Education for Women, Coimbatore, Tamilnadu, India.
}

Corresponding Author: Anto Cordelia T.A.D

Email: antoc@utar.edu.my

\begin{abstract}
The nutrition transition in Malaysia has had profound impact on the nutritional status of national population especially in children below five years. There exists paucity in the data that address the nutritional status of aboriginal children that may impair intervention programme. Hence the study aims to assess and appraise the nutritional status of Semai Orang Asli children under five years and identify the determinants of nutritional status to strengthen baseline data. A total of 340 Semai children (179 males and 161 female children from Perak were recruited for the study. All information pertaining to demographic, socio-economic and educational status were collected using an interviewer-administered questionnaire. All children were subjected to nutritional anthropometry and clinical examination using standard procedures. A one-day dietary record was done on a sub-sample of 140 children between 12 and 59 months. About $32.7 \%$ of the Semai children were underweight $28.2 \%$ were stunted and 52\% showed wasting. Body Mass Index (BMI) revealed 52\% of children with moderate to severe thinness. The existence of malnutrition was higher among female children. Twentyeight percent were identified with any form of nutritional deficiencies and did not meet the Recommended Nutrient Intake for any measured nutrient. Poverty, illiteracy, unavailability of food, location and proximity to procure food, lack of physical activity, poor sanitation and hygiene were the contributors to the poor nutritional status. Nutrition transition has had less or marginal impact on the nutritional status of the indigenous children which calls for immediate action and intervention.
\end{abstract}

Key Words: Anthropometry, children, stunting, wasting, underweight, Orang Asli.

\section{INTRODUCTION}

Adequate nutrition is crucial for the health and development of young children. Globally, at least $35 \%$ of deaths in children less than five years of age are attributed to under nutrition either directly or indirectly. Under-nutrition is also one of the main causes of disability, which prevent children who survive from reaching their full growth development. In developing countries, an estimated $32 \%$, or 186 million children below five years of age are stunted and about $10 \%$, or 55 million, are wasted ${ }^{1}$. Under nourished children face a higher risk of mortality than well-nourished children. Childhood under nutrition results from the synergistic effects of repeated poorly treated illnesses and food inadequacy ${ }^{2}$. The prevalence of underweight, stunting, wasting and micronutrient deficiencies are evident throughout the developing world and predominant in marginalized and impoverished communities. There is also a rising concern on the elevation of overweight and obesity among young children ${ }^{3}$. Both forms of nutrition could be rooted to inappropriate feeding practices and nutrition transition that is taking place in the nation.

Malaysia is also facing this nutrition transition since the New Economic Policy era of exportoriented industrialization (1971-1990) whereby shifting from traditional ethnic diets to westernized foods. This nutrition transition has been more evident among the high and middleincome groups. Low income and the indigenous communities still lag behind in their nutritional status with more Orang Asli children being undernourished. According to the Third National Health and Morbidity Survey (NHMS III) ${ }^{4}$ conducted nationwide in 2006, $12.9 \%$ children aged 0-59.9 months were reported to be underweight and $17.2 \%$ were stunted. This included $2.4 \%$ and $6.0 \%$ of severe underweight and severe stunting respectively. A corresponding decline in the mean WAZ and HAZ was seen after about 6 months ${ }^{5}$. But there was no special mention with regard to the indigenous Orang Asli children on the mean HAZ and WAZ. Based on BMI -for-age and WAZ, the prevalence of overweight for both sexes combined were $6.4 \%$ and $3.4 \%$, respectively, which visualizes 
the shift in nutrition status from under-nutrition towards overweight and obesity.

The "Orang Asli" are the indigenous minority of Malaysia and represent $0.7 \%$ of the total population ${ }^{6}$. They are divided into three ethnic groups namely the Senoi, the Negritos and the Proto-Malay. The Senoi are the largest ethnic groups and distributed mainly in the states of Pahang and Perak. Perak hosts nearly two thirds of the total Orang Asli population of Peninsular Malaysia. Report from the Department of Statistics $(2010)^{7}$ revealed that $76.9 \%$ of Orang Asli live below the poverty line and an alarming $35.2 \%$ of all Orang Asli were dwelling in hard core poverty, whose monthly income is less than half of the poverty line income. The Orang Asli children are not the only tribes to be inflicted with undernutrition. More than half the adult aborigines in Australia are overweight and obese with half of the children being underweight and stunted ${ }^{8}$. Similarly, reports from the First National Survey of Indigenous People in Brazil also show that $46.1 \%$ of the indigenous adults were overweight and obese whereas $26 \%$ and $6 \%$ of the children were stunted and underweight ${ }^{9,10}$. The economic transformation and nutrition transition has less impact on the aborigines worldwide.

Comprehensive studies are required to fill the attrition in data level with regard to nutritional status and food intake among the aborigines and economically impoverished. Hence the current study aimed to assess and appraise the nutritional status of the Semai children and throw light on the factors that predominantly impair their health and nutritional status. Also the current study would embark on strengthening the baseline information with special reference to Semai indigenous community and Orang Asli in general.

\section{METHODS}

\section{Study population}

The Senoi are the largest group of Orang Asli in Peninsular Malaysia and is further divided into six sub-ethnic groups (reference). The Semai community being widespread and larger in Perak, it would represent Senoi group and overall the indigenous population of Peninsular Malaysia.

\section{Study Design and Sampling Technique}

\section{Study Design}

The current study is part of a cross-sectional population based epidemiological study carried out in tribal setting involving the Semai indigenous community dwelling in the geographic terrain nearly three months prior to the study and until the survey period (2012-2014).

\section{Sampling Procedure}

\section{Sample size estimation}

The sample size was calculated using a formula proposed by Daniel (1999) ${ }^{11}$ for the estimation of a population proportion with a specified relative precision (25) as follows:

$$
n=\frac{Z^{2} P[1-P]}{d^{2}}
$$

Where $\mathrm{n}$ is the required sample size, $\mathrm{Z}$ is the statistic corresponding to level of confidence, $P$ is expected prevalence and $\mathrm{d}$ is precision (corresponding to effect size).

Assuming the overall nutritional insufficiency to be 40 percent as reported by Yusuf et al ${ }^{12}$. among the Orang Asli population and using a Confidence Interval $(\mathrm{Cl})$ of 95 percent, relative precision of 10 percent and design effect of 2, the estimated sample size was 383 households.

\section{Sampling Techniques}

The sampling for this study was done with assistance from the Department of Orang Asli Affairs JAKOA, Perak, Malaysia. In order to ensure representative samples, stratified sampling was adopted in the survey. The assessment was done on seven districts inhabited by Semai aborigines and each district is considered as a primary stratum, and the secondary stratum is formed by the villages or village zones (urban and interior) formed within the primary stratum. The standard stratified cluster sampling technique was used to select the 40 clusters (also referred to as primary sampling unit - (PSUs) or village zones in each district using the latest comprehensive list of all villages obtained from JAKOA, Perak applying the Probability proportion to size (PPS) technique. The secondary sampling unit (SSU) was the households $(\mathrm{HHs})$ within each selected village zone. From the list of villages obtained from JAKOA, a total of 40 village zones were selected, with 26 and 14 village zones selected from the rural and interior areas, respectively. All children between the age group of 0-59 months within the selected households were included in the study. Hospitalized children and children suffering from chronic illnesses were excluded from the study.

\section{Study Instruments}

\section{Demography and Socio-economic Background}

The information pertaining to the socio economic data and demographic details were collected using face-to-face interview through a pre-tested and validated questionnaire. The questionnaire was adopted from the National Nutrition Monitoring Bureau $^{13}$ developed by the National Institute of Nutrition, India with modifications to fit the 
Malaysian indigenous community. The questionnaires were designed in English and translated into Aslian language with the locals in the field set up.

\section{Assessment of Nutritional Status}

\section{Diet Survey}

A one-day 24-hour recall method of diet survey was carried out on a subsample $(n=140)$ to assess the food and nutrient intake. Special events and functions at home were excluded as it might affect the usual habitual dietary intake. The mother/care giver of the respective child was requested to remember in detail all the foods and drinks they administered during the preceding 24-hours. Household measuring cups, ladles and utensils for different portion size along with pictures depicting the amounts was shown to get the proper portion size. Different time frames like after waking, during teatime or after school were used to extract the details of food and drinks consumed. Also a detailed method of cooking food was obtained from the mothers' / care givers in the households who prepared the food.

\section{Nutritional Anthropometry}

Height was measured as recumbent length or standing height, the former for infants and young children using a measuring mat (SECA 210, Germany) to measure the recumbent length to the nearest $0.1 \mathrm{~cm}$ and standing height of young children ${ }^{14}$. A digital infant meter was used to weigh the infants and the body weight of children to nearest $0.1 \mathrm{~kg}$. The subjects were measured with light clothes and shoes removed. Mid Upper Arm Circumference was measured on the left upper arm half way between the end of the shoulder using a non-stretchable fiber glass tape to the nearest $0.1 \mathrm{~cm}^{15}$. Skin fold measurement at triceps was measured using Harpenden skin fold calipers to the nearest $0.1 \mathrm{~mm}$. All measurements were taken in duplicates and the average value was taken for the data entry.

\section{Clinical examination}

A comprehensive physical and clinical examination was carried out with the help of trained public health nurse and paramedical staff on all the children covered for anthropometry to examine for the presence of clinical signs that are imperative of nutritional deficiencies ${ }^{16}$. A child was classified as suffering from protein-calorie malnutrition if he/she suffered from any one or more of the following symptoms: edema, dyspigmentation of the hair, easy pluckability of the hair, thin sparse hair, muscle wasting, moonface, flaky-paint rash, and dermatosis. With regard to vitamin A deficiency, the following signs were considered: xerosis of the conjunctivae, Bitot's spots and cornea whereas angular stomatitis, cheilosis, glossitis and atrophic or hypertrophic lingual papillae are signs of deficiency of the B-complex vitamins. Discrete or confluent pitting, with widespread brown staining and a general, corroded appearance were considered for dental fluorosis while cavities and molecular decay of a tooth which is thinned, and dark, and gradually breaks down with the formation of pus was assessed for dental caries. Spoon-shaped nails/concave nails (koilonychia) for iron deficiency; and enlargement of thyroid (front of neck) was assessed for iodine deficiency. Only non-invasive methods were used for assessment.

\section{Data Analysis, Interpretation and Inference}

Data analysis was done statistical tools such as WHO Anthro Plus and SPSS version 17. Most of the data are presented in percentages. The comparison of outcomes between genders was done using independent $t$-test. The association of continuous data was done using Analysis of variance (ANOVA) and Chi-square test was performed to establish possible difference between groups. The association between anthropometric measurements, socio-economic and other demographic factors was established using Pearson's correlation. For all analysis performed, a probability value of $\mathrm{p}<0.05$ was considered as significant.

Diet and Nutritional Status

\section{Food and Nutrient intake of individuals}

The average intake of different foods based on serving size was calculated according to age/sex and physiological status. The average nutrient consumption was computed using the Food Composition Table, Malaysia ${ }^{17}$ and The Malaysian Dietary Guidelines $(2010)^{18}$. The intake of various foods and their nutrient composition were compared with the Recommended Nutrient Intakes for Malaysia $(2015)^{19}$.

\section{Protein /Calorie Adequacy Status}

The protein and energy requirement curves are assumed to follow Gaussian distribution or 'normal distribution, with a coefficient of variation of $12.5 \%$ for growth according to the revised RNI suggested by the Technical Sub-Committee (TSC) ${ }^{19}$. Using the cut-off levels, based on RNI, the energy/protein adequacy status for each group was determined. Consuming protein and /or energy in amounts less than mean -2SD of the prescribed requirements were considered as consuming 'inadequate' amounts.

Anthropometry

Infants and children of 0-59 months (0-5years) were classified into various nutritional grades 
according to standard deviation (SD) classifications by using WHO Growth Standards $(2006)^{14}$

\section{Ethics Approval and Informed Consent}

The research protocol and survey instruments were approved by the Ethical Research Committee of University Tunku Abdul Rahman (U/SERC/23/2014) and Avinashilingam Institute for Home Science and Higher Education for Women (India) (AUW/IHEC14-15/XPD-03). Permission was also obtained from JAKOA (Department of Orang Asli Affairs), Perak, Malaysia (JHEOA.PP.30.052Jld.6 (26) prior to data collection. The informed consent was obtained from either the head of the family or from their mothers. The identity (names, IC. number and addresses) was not recorded in the questionnaire or information form. Confidentiality of the data was assured to all participants.

\section{RESULTS}

A total of 340 children between 0-59.9 months participated in the study. For better understanding and interpretation, the anthropometric and clinical examination were discussed following the distribution of age groups as 0-5 months, 6-11 months, 12-35 months and 36-59 months. The assessment of food and nutrient intake follows the age group as given by the NCCFN (2005) for comparison with the RNI.

\footnotetext{
Prevalence of Stunting, Wasting and Underweight among Semai Children

Wasting also referred as acute malnutrition that to be present for a short duration. The mean $\mathrm{WHZ}$ of the children deviates from the WHO reference median $(-2.33)$ and the deviation is wide in case of males $(-2.05)$ compared to females $(-1.96)$. The highest deviation of mean was recorded among infants of 6-11 months $(-2.72$ and -2.42 , respectively) which shows that faltering of body weight occur after six months and coincidentally this is the transition period where the infant is introduced with complementary feeds and weaned off-breast milk. Contradictory to wasting, stunting, referred to as chronic energy deficiency is characterized by accumulated severe energy deficiency over a longer duration (reference).
}

Indicated by length/height-to-age (HAZ), the overall prevalence is estimated to be 21.5 percent $(\mathrm{Cl}-17 \%, 26 \%)$ within which 11.2 percent $(\mathrm{Cl}-7.7 \%$, $14.7 \%)$ are severely stunted.

Children between the age group of 24-35 months and $12-23$ months are most inflicted with stunting with an estimated prevalence of $54.2 \%(\mathrm{Cl}-40.7 \%$, $67.8 \%)$ and $27.2 \%(\mathrm{Cl}-16.9 \%, 37.5 \%)$, respectively. Majority of the boys $(24 \%, \mathrm{Cl}-17.5 \%, 30.6 \%)$ have stunted growth compared to girls $(18.6 \%, \mathrm{Cl}$ : $12.3 \%, 25 \%)$. The mean WAZ of the Semai children shifted towards the left as against the WHO reference median $(-1.83)$ and is evident in males (1.92) compared to females $(-1.73)$. The overall prevalence of underweight is 12 fold greater than NHMS III and six times greater than the NHMS IV results. Overall, 14 percent of boys and eight percent of girls were severely undernourished reckoning severe acute malnutrition (SAM). The $\mathrm{BMI}$ in general was relatively poor when compared with the reference median and mean values of NHMS III. The mean value of BMI in overall is -1.83 , which again deviates from the reference median. The deviation is more widely present in males ($2.01)$ as against $(-1.93)$ in females. The mean $z$ scores of <-2SD which underlines moderate thinness is widespread among all groups in both sexes $(57.5 \%$ and $52.2 \%)$, respectively. No uniform increase or decrease in prevalence rate is seen in both genders as the increase or decrease follows a mixed trend.

None of the children was found to be overweight. The ratio of stunted children among Orang Asli is significantly $(\mathrm{p}<0.05)$ higher compared to the data reported in NHMS III (17.2\%) and NHMS IV (17.7\%). As seen from Table 2 the percentage of stunted children has increased from that in 2006 to 2015. Yet the figures are lower than the current study. Though the prevalence rate for both sexes is equal in NHMS III, a slight increment in stunting was found among girls in NHMS IV. Contradictory to the Semai children, female children are more malnourished in NHMS IV. The difference in prevalence rate for underweight of Semai children, NHMS III and IV is statistically significant $(p<0.05)$ in all children as well as between the genders. 
Table 1: Distribution of Semai Children (0-59 months) by gender based on nutritional status according to Z-score classification using WHO standards

\begin{tabular}{|c|c|c|c|c|c|c|c|}
\hline \multicolumn{8}{|c|}{ Weight-for-length/height - Wasting } \\
\hline Gender & $\mathbf{N}$ & Percent $<-3 S D$ & Percent $<-2 S D$ & Percent $>+1 \mathrm{SD}$ & Percent $>+2 S D$ & Mean & SD \\
\hline Male & 179 & 16.2 & 59.2 & 0.6 & 0 & -2.05 & 0.97 \\
\hline Female & 161 & 8.1 & 53.4 & 1.2 & 0.6 & -1.96 & 0.88 \\
\hline Total & 340 & 12.4 & 56.5 & 0.9 & 0.3 & -2.01 & 0.93 \\
\hline \multicolumn{8}{|c|}{ Length/height-for-age - Stunting } \\
\hline Gender & $\mathbf{N}$ & Percent & Percent $<-2 S D$ & Mean & SD & & \\
\hline Male & 179 & 14 & 24 & -0.91 & 1.59 & & \\
\hline Female & 161 & 8.1 & 18.6 & -0.63 & 1.53 & & \\
\hline Total & 340 & 11.2 & 21.5 & -0.78 & 1.57 & & \\
\hline \multicolumn{8}{|c|}{ Weight-for-age - Underweight } \\
\hline Gender & $\mathbf{N}$ & Percent $<-3 S D$ & Percent $<-2$ SD & Mean & SD & & \\
\hline Male & 179 & 14 & 48.6 & -1.92 & 0.96 & & \\
\hline Female & 161 & 13.7 & 34.2 & -1.73 & 0.98 & & \\
\hline Total & 340 & 13.8 & 41.8 & -1.83 & 0.97 & & \\
\hline \multicolumn{8}{|c|}{ BMI-for-age (percent) } \\
\hline Gender & $\mathbf{N}$ & Percent $\quad<-3 S D$ & percent $<-2 S D$ & Percent $>+1$ SD & Percent $>+2 S D$ & Mean & SD \\
\hline Male & 179 & 18.4 & 57.5 & 2.2 & 0 & -2.01 & 1.1 \\
\hline Female & 161 & 9.3 & 52.2 & 1.2 & 0.6 & -1.93 & 0.92 \\
\hline Total & 340 & 14.1 & 55 & 1.8 & 0.3 & -1.97 & 1.02 \\
\hline \multicolumn{8}{|c|}{ Mid-upper arm circumference-for-age** (percent) } \\
\hline Gender & $\mathbf{N}$ & Percent $<-3 S D$ & Percent $<-2 S D$ & Percent $>+1$ SD & Percent $>+2 S D$ & Mean & SD \\
\hline Male & 172 & 4.7 & 25.6 & 3.5 & 1.2 & -1.14 & 1.18 \\
\hline Female & 155 & 3.9 & 20 & 0.6 & 0 & -1.04 & 1.07 \\
\hline Total & 327 & 4.3 & 22.9 & 2.1 & 0.6 & -1.09 & 1.13 \\
\hline \multicolumn{8}{|c|}{ Triceps skinfold-for-age** (percent) } \\
\hline Gender & $\mathbf{N}$ & Percent & Percent $<-2 S D$ & Percent $>+1$ SD & Percent $>+2 S D$ & Mean & SD \\
\hline Male & 172 & 13.4 & 50.6 & 0 & 0 & -1.93 & 0.91 \\
\hline Female & 155 & 9.7 & 41.3 & 0 & 0 & -1.91 & 0.74 \\
\hline Total & 327 & 11.6 & 46.2 & 0 & 0 & -1.92 & 0.83 \\
\hline
\end{tabular}

For each indicator all children are included in the evaluation with a plausible z-score (defined under Survey options). percent<-2SD includes percent<-3SD; percent $>+2 S D$ includes percent $>+3 S D$; percent $>+1 S D$ includes percent $>+2 S D$ and percent $>+3 S D$. $\left({ }^{* *}\right) 3$ months is the lowest age for this indicator.

Prevalence of malnutrition as assessed by arm circumference and skin fold thickness

In general, 22.9 percent, $(\mathrm{Cl}: 18.2 \%, 27.6 \%)$ of the Semai children had malnourished arm circumference with 4.3 percent $(\mathrm{Cl}: 1.9 \%, 6.6 \%)$ presenting severe acute malnutrition. Older children (48-60 months) exhibited poor arm circumference $(46.1 \%, \mathrm{Cl}: 35.1 \%, 57 \%)$. The prevalence of malnutrition as assessed by MUAC was distributed throughout all groups at different levels. Boys had poor arm circumference $(25.6 \%)$ compared to females (20 percent). More than $50 \%$ of the males and $41.6 \%$ of the females are predicted with less subcutaneous fat with $13.4 \%$ of males and 9.7 percent of females showing severe loss of body fat. The fat composition increases as age increases and yet it is low and widespread among all age groups and both gender. 
Table 2: Comparison of Nutritional Status of Semai Children with National Reference Population (NHMS III) and (NHMS IV)

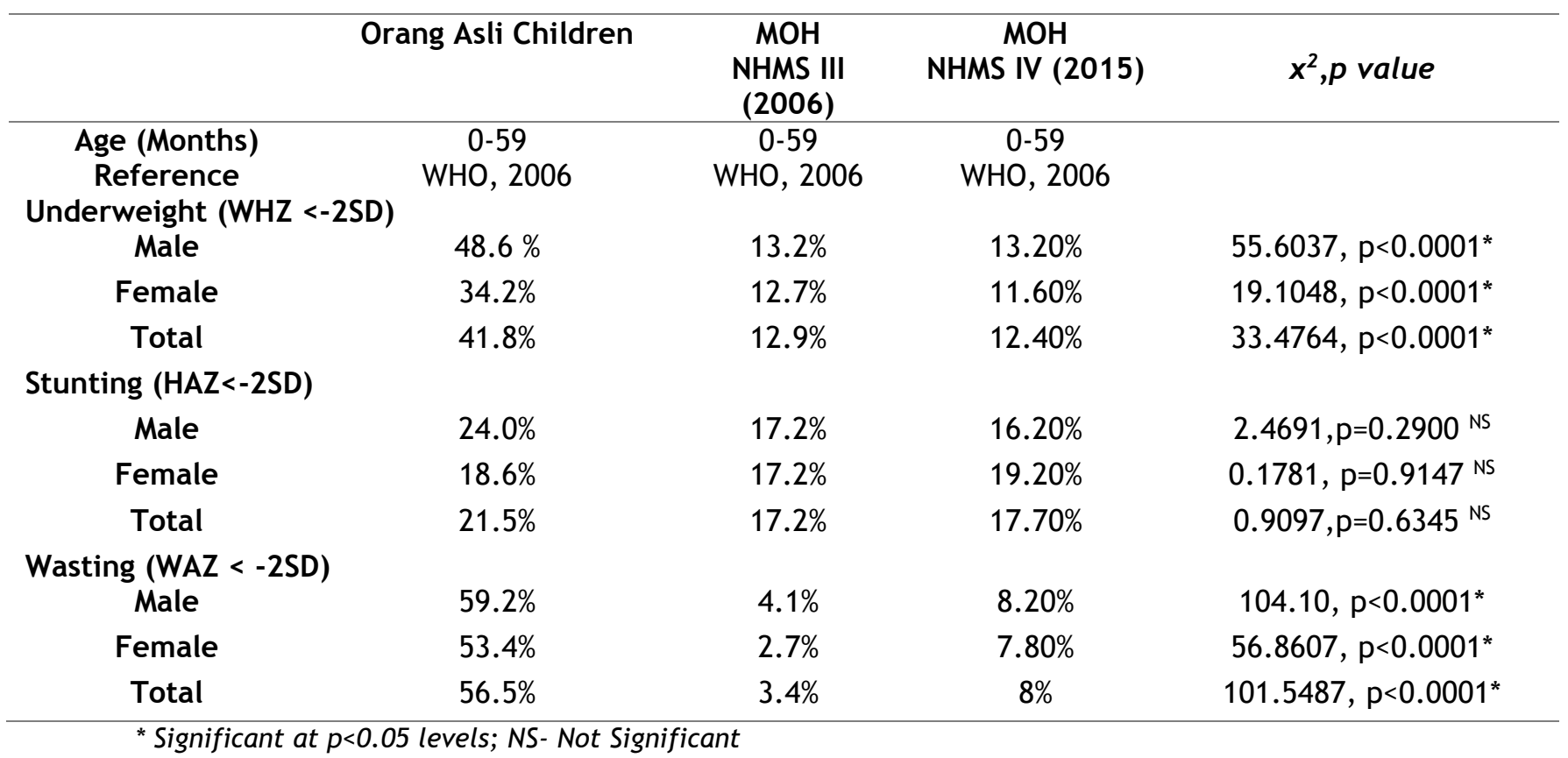

Table 3: Protein and Calorie Adequacy Status of Semai Children (1-5 years)

\begin{tabular}{clccccc}
\hline \multicolumn{1}{c}{ Age Group } & \multicolumn{2}{c}{ Gender } & $\mathrm{P}+\mathrm{C}+$ & $\mathrm{P}+\mathrm{C}-$ & $\mathrm{P}-\mathrm{C}+$ & $\mathrm{P}-\mathrm{C}-$ \\
\hline 12 to 35 months & Male $\quad(\mathrm{N}=74)$ & $16(21.62 \%)$ & 0 & $16(21.62 \%)$ & $42(56.75 \%)$ \\
& Female $(\mathrm{N}=66)$ & $46(68.66 \%)$ & $1(1.5 \%)$ & $5(7.46 \%)$ & $14(22.39 \%)$ \\
\multirow{3}{*}{ 36-59 months } & Male $(\mathrm{N}=26)$ & $5(20 \%)$ & $2(7.5 \%)$ & 0 & $19(72.5 \%)$ \\
& Female $(\mathrm{N}=28)$ & $4(14 \%)$ & $1(4 \%)$ & $2(7 \%)$ & $21(75 \%)$ \\
\hline
\end{tabular}

$P+C+\quad$ Protein Adequate; Calorie Adequate; $P+C$ - Protein Adequate; Calorie Inadequate

$\mathrm{P}-\mathrm{C}+\quad$ Protein Inadequate; Calorie Adequate; P-C-Protein Inadequate; Calorie Inadequate

Prevalence of common nutritional deficiencies

The common nutritional deficiencies prevalent among the Semai children were PEM (33.57\%), vitamin A deficiency $(14.55 \%)$, riboflavin deficiency $(11.56 \%)$ dental caries $(5.04 \%)$, dental fluorosis $(8.6 \%)$ iodine deficiency $(1.38 \%)$ vitamin $D$ deficiency $(4.17 \%)$ vitamin C deficiency $(11.5 \%)$ and iron deficiency (4.7\%). 


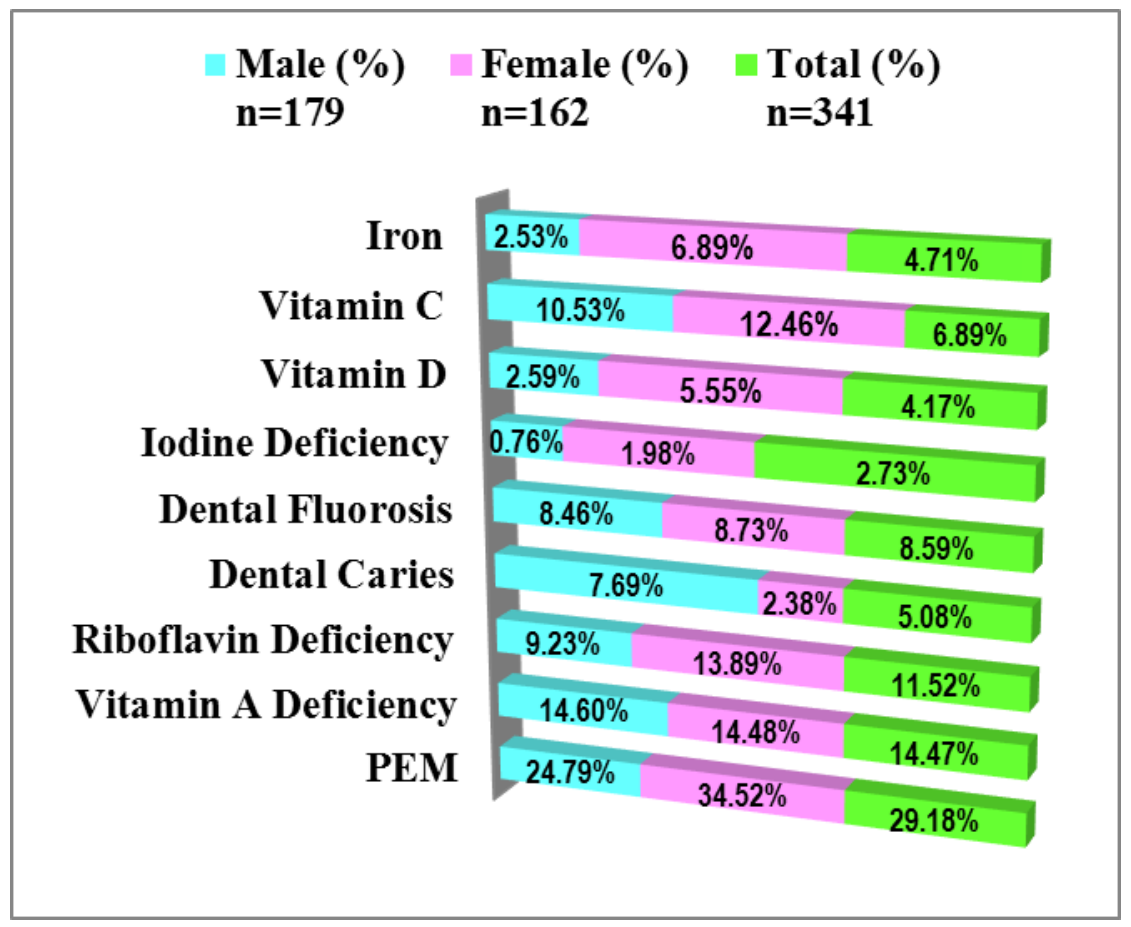

Figure 1: Prevalence of Sub-clinical measures among Semai Children (0-59 months)

\section{Food and Nutrient Intake of Children}

The mean consumption of nutrients from food groups among children of 1-3 years and 4-5 years are presented in Figure 2 (a), (b).

Cereals and tubers formed the major constituent in the meals of Semai children as they were introduced with complementary foods, which is rice and sago porridge. Pulses were consumed in lower amounts in both age groups. Green leafy and other leafy vegetables were not included much in their meal and consumption of fruits depended on seasonal availability. Fish and other flesh foods were given along with porridge and rice and yet could meet only 30 \%of their daily requirements. Milk was the second highly consumed food among the Semai children as some children still continued with breast milk and some supplemented with formula milk and other milk sources. In all, lack of dietary diversity was most obviously witnessed in the food intake of Semai children.

The Semai children did not meet the requirements for any nutrients in both genders. The food consumption by pre-school children is characterized by sub-optimal levels of intakes of calories and most nutrients. The intake of energy and other macro and micro nutrients were higher among boys in both groups than among girls in the current study. The energy intake of children in toddler age group was much better compared to the older children (4-5 years) and similar pattern was observed in both gender. When compared with the micronutrient intake, the levels of intake were much below the recommended levels and lowest intake was recorded for riboflavin in both gender which is less than $50 \%$ of RNI amongst 4-6 years old but it was better in 1-3 years old children with $56 \%$ and $62 \%$ of $\mathrm{RNI}$ for girls and boys respectively. Intake of dietary Vitamin $\mathrm{C}$ and vitamin A was less among older children compared to the younger children. Greater than $70 \%$ of recommended intake for iron and folates are met by children of $1-3$ years while older children consumed only $\leq 60 \%$. The mean intake for protein, calcium and thiamin exceeded $70 \%$ among 1-3 years old children and $60 \%$ in $4-5$ years old and no significant difference in intake was found between genders for all nutrients.

The protein and calorie adequacy status of Semai Children is given in table 3 . Female children showed better protein and calorie adequacy status compared to boys in toddler group although a sharp decline in percentage was observed in preschool age. Contradictory to the toddler groups, boys have better protein and calorie status in preschool age. 


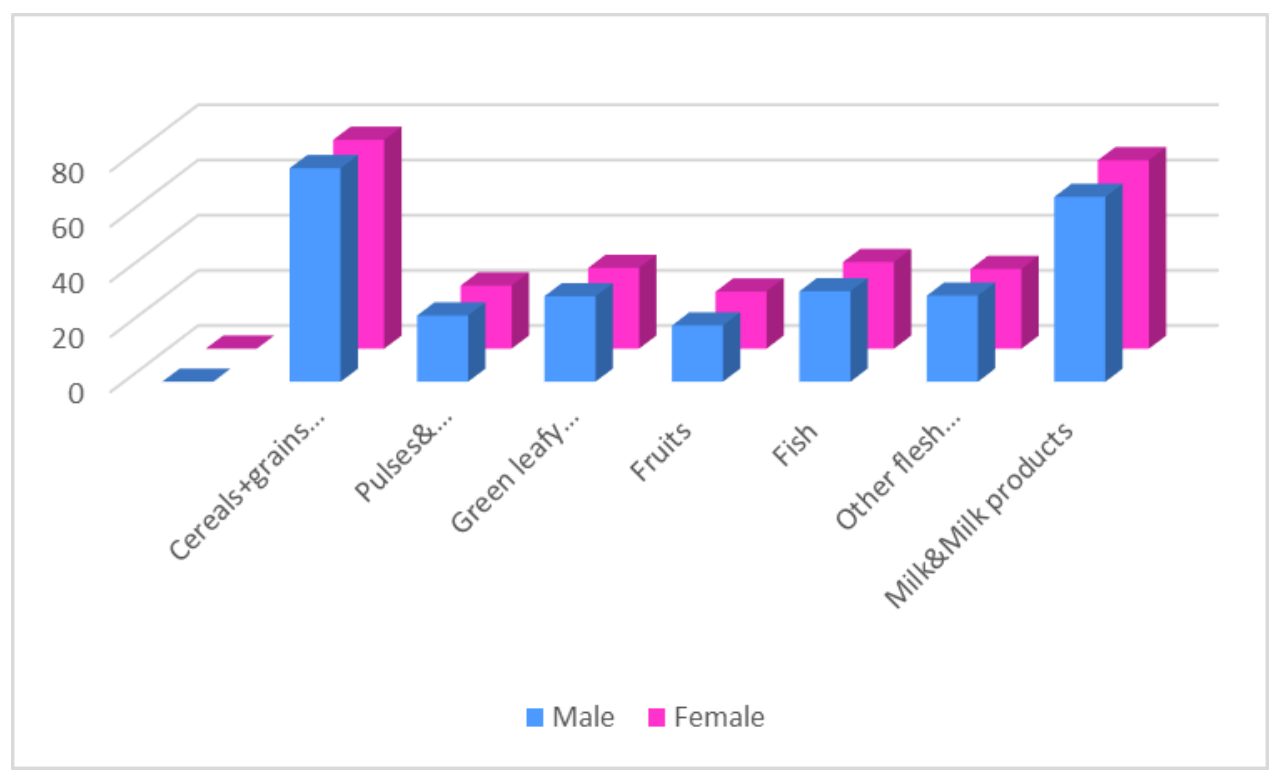

Figure 2 (a): Percent consumption from food groups as percent RNI among Semai children

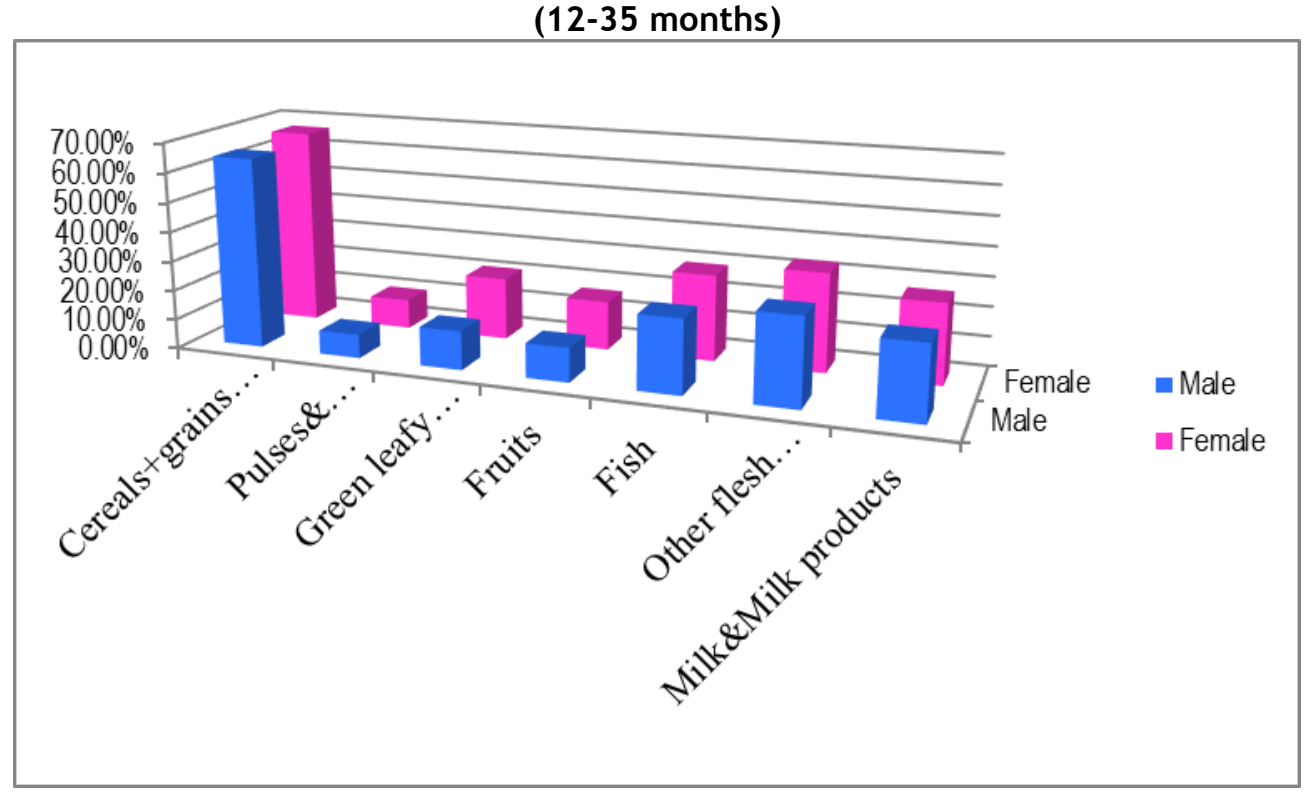

Figure 2 (b): Percent consumption from food groups as percent RNI among Semai children (36-59 months)

Socio-Demographic Factors Associated with Nutritional Status of Semai Children

Nuclear family and smaller family size enjoyed better nutritional status compared to extended nuclear or joint family and it is found to influence stunting, wasting and underweight. Education status of father significantly affected wasting and underweight while educational status of mother showed significant association $(P<0.05)$ with underweight children. Children who hail from family with per capita income less than RM 100 exhibited poor nutritional status. A household, which uses LPG as cooking fuel, had better nutritional status compared to those using firewood. The presence and use of sanitary latrines have positive influence in wasted and underweight children. Presence of separate kitchen in households affected stunted and underweight children. 


\section{DISCUSSION}

Evidence from various studies on Orang Asli of different ethnic groups also show similar results with more than 50 percent of Orang Asli children look stunted ${ }^{20-23}$. According to the UNICEF-WHOWorld Bank Joint Child Malnutrition Estimates $(2012)^{25}, 52$ million children or 8 percent of the children below five years globally were estimated to be stunted in $2011^{25}$. WHO $(1997)^{26}$ stated that $>5$ percent prevalence rate of wasting is alarming and that of $>15$ percent is critical. The major cause of wasting in children is believed to be very low intake of energy and infection especially diarrhea and vomiting.

Table 4a: Socio-Demographic Factors Associated with Nutritional Status of Children (0- 59 Months) Based on SD Classification

\begin{tabular}{|c|c|c|c|c|c|c|c|}
\hline Particulars & $\mathrm{n}$ & $\begin{array}{l}<\text { Median } \\
-2 S D\end{array}$ & $\begin{array}{l}\geq \text { Median } \\
-2 S D\end{array}$ & $\begin{array}{l}<\text { Median } \\
-2 S D\end{array}$ & $\begin{array}{l}\geq \text { Median } \\
-2 S D\end{array}$ & $\begin{array}{l}<\text { Median } \\
-2 \text { SD }\end{array}$ & $\begin{aligned} \geq & \text { Median } \\
& -2 S D\end{aligned}$ \\
\hline \multicolumn{8}{|c|}{ 1. Type of Family $(\mathrm{N}=340)$} \\
\hline $\begin{array}{l}\text { Nuclear + } \\
\text { Extended }\end{array}$ & 324 & 39.81 & 60.19 & 20.37 & 79.63 & 54.62 & 45.37 \\
\hline $\begin{array}{l}\text { Joint } \\
x^{2}, p \text { value }\end{array}$ & 16 & \multicolumn{2}{|c|}{$35.171, p<.00001, S$} & \multicolumn{2}{|c|}{$13.2353, p=.000275, S$} & \multicolumn{2}{|c|}{$40.0316, p<.00001, S$} \\
\hline \multicolumn{8}{|l|}{ 2. Family Size } \\
\hline $1-4$ & 108 & 27.78 & 72.22 & 12.96 & 87.04 & 38.89 & 61.11 \\
\hline $5-7$ & 218 & 45.87 & 54.12 & 23.39 & 76.61 & 62.84 & 37.16 \\
\hline$>7$ & 14 & 85.71 & 14.29 & 57.14 & 42.86 & 92.86 & 7.14 \\
\hline$x^{2}, p$ value & & \multicolumn{2}{|c|}{$24.8285, p<.00001, S$} & \multicolumn{2}{|c|}{$63.3198, p<.00001, S$} & \multicolumn{2}{|c|}{$66.378, p<.00001, S$} \\
\hline \multicolumn{8}{|c|}{ 3. Educational status of Father } \\
\hline $\begin{array}{l}\text { Formal } \\
\text { education }\end{array}$ & 74 & 28.37 & 71.62 & 20.27 & 79.73 & 16.67 & 83.33 \\
\hline $\begin{array}{l}\text { No formal } \\
\text { education }\end{array}$ & 266 & 45.48 & 54.51 & 21.8 & 78.2 & 63.53 & 36.47 \\
\hline$x^{2}, p$ value & & \multicolumn{2}{|c|}{$6.2345, .0125, s$} & \multicolumn{2}{|c|}{$0.1206, p=0.728, N S$} & \multicolumn{2}{|c|}{$45.8346, p<.00001, S$} \\
\hline \multicolumn{8}{|c|}{ 4. Literacy Status of Mother } \\
\hline $\begin{array}{l}\text { Formal } \\
\text { education }\end{array}$ & 58 & 31.03 & 68.97 & 20.68 & 79.32 & 25.86 & 64.14 \\
\hline $\begin{array}{l}\text { No formal } \\
\text { education }\end{array}$ & 282 & 43.97 & 56.03 & 21.63 & 78.37 & 62.76 & 37.23 \\
\hline$x^{2}, p$ value & & \multicolumn{2}{|c|}{$3.6053, p=.0575, N S$} & \multicolumn{2}{|c|}{$0.0296, p=0.8633, N S$} & \multicolumn{2}{|c|}{$22.1348, p<.00001, S$} \\
\hline \multicolumn{8}{|c|}{ 5. Occupation of father } \\
\hline Working & 319 & 41.06 & 58.93 & 20.69 & 79.31 & 55.17 & 44.83 \\
\hline $\begin{array}{l}\text { Not } \\
\text { working }\end{array}$ & 21 & 57.14 & 42.86 & 42.85 & 57.14 & 76.19 & 23.81 \\
\hline$x^{2}, p$ value & & \multicolumn{2}{|c|}{$5.122, p=0.0236, S$} & \multicolumn{2}{|c|}{$11.1213, p=.000853, S$} & \multicolumn{2}{|c|}{$9.7577, p=.001786, S$} \\
\hline \multicolumn{8}{|c|}{ 6. Occupation of mother } \\
\hline Working & 87 & 85.05 & 14.95 & 48.27 & 51.72 & 89.66 & 10.34 \\
\hline $\begin{array}{l}\text { Not- working } \\
x^{2}, p \text { value }\end{array}$ & 253 & $\begin{array}{l}26.87 \\
68.263, p<\end{array}$ & $\begin{array}{l}73.13 \\
0001, s\end{array}$ & $\begin{array}{l}12.25 \\
30.8571, p\end{array}$ & $\begin{array}{l}87.75 \\
0001, s\end{array}$ & $\begin{array}{l}45.06 \\
46.1538, p<\end{array}$ & $\begin{array}{c}54.94 \\
.00001, \mathrm{~s}\end{array}$ \\
\hline \multicolumn{8}{|c|}{ 7. Per Capita Income (Rm) } \\
\hline$\leq 100$ & 105 & 84.76 & 15.24 & 46.66 & 53.33 & 86.67 & 13.33 \\
\hline $101-300$ & 232 & 22.84 & 77.16 & 10.34 & 89.66 & 43.53 & 56.47 \\
\hline$\geq 300$ & 3 & & 100 & 0 & 100 & 0 & 100 \\
\hline$x^{2}, p$ value & & \multicolumn{2}{|c|}{$68.263, p<.00001, S$} & \multicolumn{2}{|c|}{$33.591, p<.00001, S$} & \multicolumn{2}{|c|}{$40.9116, p<.00001, S$} \\
\hline
\end{tabular}


Table 4b: Physical Facilities Associated with Nutritional Status of Children (0- 59 Months) Based on SD Classification

\begin{tabular}{|c|c|c|c|c|c|c|c|}
\hline \multirow[b]{2}{*}{ Particulars } & \multirow[b]{2}{*}{$\mathrm{n}$} & \multicolumn{2}{|c|}{ Weight-for-Age } & \multicolumn{2}{|c|}{ Height-for-age } & \multicolumn{2}{|c|}{ Weight-for-Height } \\
\hline & & $\begin{array}{l}<\text { Median } \\
-2 S D\end{array}$ & $\begin{array}{l}\geq \text { Median } \\
\quad-2 S D\end{array}$ & $\begin{array}{c}\text { <Median } \\
-2 S D\end{array}$ & $\begin{array}{l}\geq \text { Median } \\
\quad-2 S D\end{array}$ & $\begin{array}{l}<\text { Median } \\
-2 S D\end{array}$ & $\begin{array}{l}\geq \text { Median } \\
\quad-2 S D\end{array}$ \\
\hline \multicolumn{8}{|c|}{ 1. Type of House } \\
\hline PPRT\&PBR & 34 & 59.3 & 40.7 & 59.8 & 40.2 & 28.0 & 72.0 \\
\hline $\begin{array}{l}\text { Indigenous } \\
\text { houses }\end{array}$ & 306 & 71.2 & 28.8 & 60.2 & 39.8 & 36.1 & 63.9 \\
\hline$x^{2}, p$ value & & \multicolumn{2}{|c|}{$3.1648, p=.07524, N S$} & \multicolumn{2}{|c|}{$0.0, p=1, N S$} & \multicolumn{2}{|c|}{$1.4706, p=0.2252, N S$} \\
\hline \multicolumn{8}{|c|}{ 2. Source of Drinking Water } \\
\hline $\begin{array}{l}\text { Perak Water } \\
\text { Board }\end{array}$ & 41 & 24.39 & 75.61 & 21.95 & 78.05 & 53.65 & 46.35 \\
\hline $\begin{array}{l}\text { Pipe/Tank } \\
\text { water }\end{array}$ & 283 & 42.05 & 57.95 & 20.49 & 79.51 & 56.18 & 43.82 \\
\hline $\begin{array}{l}\text { River/well } \\
\text { water }\end{array}$ & 16 & 81.25 & 18.75 & 43.75 & 56.25 & 68.75 & 31.25 \\
\hline$x^{2}, p$ value & & \multicolumn{2}{|c|}{$67.9472, p<.00001, S$} & \multicolumn{2}{|c|}{$17.3441, p=.00017, s$} & \multicolumn{2}{|c|}{$5.5127, p=0.0635, N S$} \\
\hline \multicolumn{8}{|c|}{ 3. Type of cooking fuel used in the Household } \\
\hline LPG & 318 & 40.88 & 59.12 & 21.07 & 78.93 & 54.72 & 45.28 \\
\hline Firewood & 22 & 54.55 & 45.45 & 27.27 & 72.72 & 81.82 & 18.18 \\
\hline $\begin{array}{l}x^{2}, p \\
\text { value }\end{array}$ & & \multicolumn{2}{|c|}{$3.9263, p=.0475, S$} & \multicolumn{2}{|c|}{$0.9868, p=0.3205, N S$} & \multicolumn{2}{|c|}{$16.8926, p=.00004, S$} \\
\hline \multicolumn{8}{|c|}{ 4. Presence of Electricity } \\
\hline Present & 270 & 40 & 60 & 20 & 80 & 53.33 & 46.67 \\
\hline $\begin{array}{l}\text { Absent } \\
x^{2}, p \text { value }\end{array}$ & 70 & $\begin{array}{c}48.57 \\
1.6398, p=\end{array}$ & $\begin{array}{l}51.43 \\
00347, N S\end{array}$ & $\begin{array}{c}27.14 \\
1.3628, p\end{array}$ & $\begin{array}{l}72.86 \\
24305, \text { NS }\end{array}$ & $\begin{array}{c}68.57 \\
5.3804, p=c\end{array}$ & $\begin{array}{l}31.43 \\
2036, \mathrm{~S}\end{array}$ \\
\hline \multicolumn{8}{|c|}{ 5. Presence/use of Sanitary Latrine } \\
\hline $\begin{array}{l}\text { Present \& } \\
\text { Using }\end{array}$ & 39 & 23.08 & 76.92 & 28.20 & 71.79 & 33.33 & 66.67 \\
\hline $\begin{array}{l}\text { Present but } \\
\text { don't use/ } \\
\text { Absent }\end{array}$ & 301 & 44.19 & 55.81 & 20.60 & 79.4 & 59.47 & 40.53 \\
\hline$x^{2}, p$ value & & \multicolumn{2}{|c|}{$9.8979, p=.001655, S$} & \multicolumn{2}{|c|}{$\begin{array}{c}1.3245, p=0.249785 \\
N S\end{array}$} & \multicolumn{2}{|c|}{$13.6071, p=.000225, S$} \\
\hline \multicolumn{8}{|c|}{ 6. Separate Kitchen } \\
\hline Present & 73 & 32.88 & 67.12 & 36.99 & 63.01 & 42.46 & 57.53 \\
\hline Absent & 267 & \multirow{2}{*}{\multicolumn{2}{|c|}{$\begin{array}{cc}44.19 & 55.81 \\
2.5552, p=0.10993, N S\end{array}$}} & \multirow{2}{*}{\multicolumn{2}{|c|}{ 10.1471. $p=001445, s$}} & \multirow{2}{*}{\multicolumn{2}{|c|}{$6.4826, p=.01689, S$}} \\
\hline$x^{2}, p$ value & & & & & & & \\
\hline
\end{tabular}

Stunting is a reflection of chronic under-nutrition during the critical periods of life especially during the growth and development period at early stages in a life cycle. World's stunted children accounts to 162 million $(25 \%)$ as of $2012^{27}$. In a local study by Masroor et al. ${ }^{28}$ on nutritional status of Orang Asli children in Pahang state revealed that $31.2 \%$ of the children below two years were stunted and $39.2 \%$ were wasted which is in line with the current study. Stunting among children of reference population has not changed over the past two decades ${ }^{29}$ and among the Orang Asli children who are considered as economically backward population, the stunting rate is two-fold greater than that of the national population which is alarming and draws immediate attention.

Comparison between NHMS III and NHMS IV data reveals that the rate of underweight has doubled over the past decade among the national 
population, which warrants for immediate public health action. Results by $\mathrm{Naser}^{30}$ also found that $19.6 \%$ of Orang Asli children in Pahang state were underweight which is only one-half of the prevalence in the current study. The attrition can be due to the geographic terrain and availability of health care deliveries among the Semai population. The reason for high rates of underweight among toddlers is poor hygienic practices, which lead to frequent infection and repeated episodes of diarrhea leading to weight loss.

Malnourished arm circumference, reflecting inadequate muscle protein mass and subcutaneous fat exist in significant percentages of male and female children of 3-59 months. The World Health Organization (WHO) and UNICEF ${ }^{31}$ in proposed a MUAC cut-off of $<11.5 \mathrm{~cm}$ to be one of the three nutrition tools used to identify and refer to further treatment for severe acute malnutrition. This can also be used as a proxy for wasting ${ }^{32}$. Since, MUAC grows continuously with age, and a fixed cut-off is used for screening SAM children, it helps in identifying at young age rather than with an appropriate index that is age independent such as weight-for height. Also survival is associated with fat stores during food deprivation ${ }^{33}$ and muscle mass is linked to infections ${ }^{34}$. Since younger children have low muscle mass, this puts them at a greater risk when combined with malnutrition. The Semai children are considered as high-risk population since most of them are poor and hardcore poor and the children are left malnourished.

Skinfold thicknesses is a relatively important tool to validate anthropometric indicators imperative of nutritional status, body composition and regional and total body fatness (relative subcutaneous fat distribution), with special emphasis to research settings ${ }^{35}$. Fat fold thickness at triceps which is measured as double layer of fat and skin which dates back to a long history in nutrition-related public health research to adipose tissue and can be measured non-invasively ${ }^{36}$. Around $11.9 \%$ of the Semai infants are born with a birth weight of $<2.5 \mathrm{~kg}$ with very little fat stores. It is proven that the variations in body-composition are generally ascribed to socio-economic factors, geographic terrain, environmental conditions, and genetic variations across populations ${ }^{37-40}$.

Protein and energy malnutrition is attributed to severe malnutrition arising out of dietary inadequacy of protein or calories or both and the interdependence of both. It is a fatal body depletion disorder and accounts for more number of deaths among young children especially in developed and underdeveloped countries. Amongst all, predominant calorie deficiency contributed to marasmus and severe protein deficiency lead to kwashiorkor or in most cases it is the presence of both known as marasmic kwashiorkor ${ }^{41}$. Among the social and environmental factors, poor sanitation and hygiene of the child and caregivers, availability and accessibility of health care services, geographical terrain and above all availability of food contributes to faltering in growth especially improper linear growth ${ }^{42}$.

The main cause for ocular manifestation is poor consumption of vitamin A rich foods and less intake of green leafy vegetables. There is a distinct reduction in the percentage over the decade. Malaysia is the only one Southeast Asian country that does not have any national level vitamin A prophylaxis program since the intake of vitamin A from food is sufficient to meet the daily requirements ${ }^{43}$. The government must ensure that vitamin A from food sources is sufficient enough to meet requirements especially among the marginalized community who has poor dietary diversity which lead to inadequacy.

Riboflavin deficiency is characterized by angular stomatitis, cheilosis and glossitis. Riboflavin is required by every single cell in our body and can be obtained from our daily diets and replenished every day to prevent deficiencies. The symptoms are wide spread among 1-5 years old children and the infants are spared from this deficiency due to good breast-feeding practices among the Orang Asli mothers (reference). The major cause for riboflavin deficiency is inadequate intake especially when the children are weaned off breast milk and shifted to complementary foods. Misconception that sweetened condensed milk or creamer is a source of milk and milk products was widely visible among orang asli and was administered to young children as replacement for formula milk. Condensed milkmilk that contains very less concentration of milk and milk solids and especially riboflavin compared to fresh milk and breast milk. Awareness on such misconception were elaborated to the mothers and caregivers as part of nutrition education.

In the reference Malaysian population, there is a decline in the percentage of dental caries among five years old children from 87.1 percent in 199541 to 76.2 percent in 2005, which further clarifies that young children are at high risk for increasing caries severity ${ }^{42}$. Recent evidences from literatures say that dental caries is a multifactorial disease and is entwined by genetic, behavioral, social and environmental factors ${ }^{43}$. It is one of the commonest diseases of human mankind and children are susceptible to this disease. This is mainly caused due to consumption of more 
sweetened beverages or creamer milk that is high in sugar without taking proper oral care. It was observed that most children did not brush their teeth even once a day and very little number of children used tooth brush to clean their teeth. Children need to be educated on the importance of oral care to alleviate this problem.

Dental fluorosis also termed, as mottled enamel is a condition where overexposure to fluoride occurs in childhood resulting in yellow discoloration of teeth and enamel. The major problem is with the water source. Some villages get water from the river source, some through pipes and the remaining from well water. Fluoridation of Public Water supply is ongoing and nearly $75.5 \%$ of Malaysians have access to safe and fluoridated water supply. Along with improvisation of infrastructure and educational facilities in Orang Asli villages to raise their standard of living, equal importance has to be stressed on extending fluoridated water supply to these endemic areas to further reduce oral health disparities.

The impact of IDD is less pronounced among young children in the current study whereby confirmation based on urinary iodine output and other biochemical analysis are required to further confirm the results. lodine deficiency disorder (IDD) is identified as a major public health problem throughout the world, with special mention to children and pregnant women. lodine deficiency is acclaimed as the single most preventable factor for mental retardation, which can fluctuate from mild intellectual blunting to frank cretinism and is believed to be the highly preventable cause of brain damage ${ }^{44}$.

Food choices, type of physical activity and food preferences in general account differences in higher intakes of energy and other macronutrient dense foods between gender. Boys prefer high sugar foods and fleshy foods compared to that of girls ${ }^{45}$. Nutrient intakes of children nationwide $46-49$ in a rural setting showed that the Semai children lag behind even the rural children in Malaysia in consuming inadequate nutrients in terms of quality and quantity ${ }^{50}$. Consumption of nutrients among rural children in this study was better in terms of quantity but comparatively less within their urban counterparts in the same study. Poor intake can be justified by less availability of nutrient dense food, poor purchasing capacity of food in households, decreased dietary diversity, and less intake of milk and milk products, yellow and green vegetables which are the predictors of poor nutrient intake and less compatible with RNI among these children.
The hike in the percentages for inadequacy of protein and calories among pre-school children is deemed justifiable as they are completely devoid of milk after three years with the exemption of sweetened condensed milk or creamer added along with coffee or tea. No other milk products replace milk. The second thing is less consumption of cereals and legume groups are seen among households whereby they have less access to protein rich foods - any specific reasons. The main source of protein comes from eating small fishes and other animal foods but in lesser frequencies in a week. Processed soya milk is the only other alternate source of protein in this community. Less access to the nearby towns to purchase pulses and legumes, poor income and lack of awareness on nutrition contribute to the poor protein and calorie status.

The socio-economic status of the households is centered basically around the occupational status of the $\mathrm{HH}$ head that happens to be the father in majority of households. The income of the mother complements to the household income. Fewer children are malnourished in households where the father has a regular income and those who did odd jobs and do not have regular income suffered malnutrition which is statistically significant $(p<0.05)$ in both the working status of mother and father. In the present study two-thirds of the mothers remained as housewives and did not contribute to the total family income. Most of these socio-demographic variables have proven to be predictors of malnutrition in studies conducted worldwide ${ }^{51-53}$ and among the indigenous community.

\section{CONCLUSION}

In conclusion, nutritional indicators have identified widespread chronic and existing malnutrition among the Semai children. The Semai children continue to be malnourished in spite of various intervention programs targeted to alleviate poverty and improve their health status. It is important that consideration of health status, including nutritional improvement of Semai children be incorporated into development programs. More importantly efforts need to be carried out to ensure the effectiveness of programs reaches out to the marginalized and impoverished community even in the fringes of jungle. Also the current state calls for the need for nutrition education to overcome the perils of poor health and nutrition status of community. Empowerment in terms of education and socioeconomic status with awareness on nutrition education and personal and environmental hygiene can mitigate this scenario. Attaining good nutrition is far more than what we eat; even economic 
growth or poverty reduction cannot warrant its achievement. Only a comprehensive system which guarantees to monitor the nutritional status of a nation, community or their native people can lead to sustainable development of a nation.

Financial Sponsorship: NIL

\section{Conflict of Interest}

There is no conflict of interest with regard to the study.

\section{ACKNOWLEDGEMENT}

The authors wish to thank the village heads, public health nurses, and all participants for their willingness, co-operation and help rendered during the course of study.

\section{REFERENCES}

1. Philip RR, Vijayakumar K, Indu PS, Shrinivasa BM, Sreelal TP, Balaji J. Prevalence of undernutrition among tribal preschool children in Wayanad district of Kerala. Int J Adv Med Health Res 2015; 2:33-8

2. Pelletier DL, Frongillo EA, Jr, Schroeder DG, Habicht JP. The effects of malnutrition on child mortality in developing countries. Bulletin of the World Health Organization 1995; 73: 443448

3. World Health Organization. 2008-2013 action plan for the global strategy for the prevention and control of noncommunicable diseases: prevent and control cardiovascular diseases, cancers, chronic respiratory diseases and diabetes. Geneva: WHO; 2009.

4. Institute for Public Health (IPH) National Health and Morbidity Survey 2011 (NHMS 2011) Kuala Lumpur: Ministry of Health Malaysia; 2011.

5. Institute for Public Health (IPH) 2015. National Health and Morbidity Survey 2015 (NHMS2015). Vol. II: Non-Communicable Diseases, Risk Factors \& Other Health Problems; 2015.

6. Jabatan Kemajuan Orang Asli (JAKOA). Online: http://www.jakoa.gov.my/orangAsli/ (accessed 16 March 2015).

7. Department of Statistics Malaysia. 2010. Profile of Orang Asli in Peninsular Malaysia.
8. Burns J, Thomson N (2008) Review of nutrition and growth among Indigenous peoples. Retrieved [access date] from http://www.healthinfonet.ecu.edu.au/he alth-risks/ nutrition / reviews/our-review.

9. Horta, 2013. Nutritional status of indigenous children: findings from the First National Survey of Indigenous People's Health and Nutrition in Brazil. International Journal for Equity in Health, 12:23.

10. Coimbra, C.E.A., Santos, R.V., Welch, J.R., Cardosa, A.M., Souza, M.C. and Garnelo, L. The first national survey of indigenous people's health and nutrition in Brazil: rationale, methodology, and overview of results. BMC Public Health 2013; 13: 13.

11. Daniel WW. Determination of sample size for estimating proportions. Biostatistics $A$ foundation for analysis in the health sciences. 1999; 8:189-90.

12. Yusof, J., Perubatan Tradisional: Upacara Tradisional dan Pantang Larang Komuniti Semai di Daerah Batang Padang, Tapah, Perak.

http://www.jakoa.gov.my/en/web/guest/ abstrakkajian.Diakses pada: 25 Julai 2013

13. NNMB third repeat survey (2012). Diet and Nutritional Status of Rural Population.

14. WHO, 2006. Multicentre Growth Reference Study Group. WHO child growth standards: length/height-for-age, weight-for-age, weight-for-length and body mass index-forage: Methods and Development. Geneva.

15. WHO, 1995. Physical status: the use and interpretation of anthropometry. WHO Technical Report Series. Geneva, Switzerland: World Health Organization (WHO).

16. Jelliffe, D.B., 1966. The assessment of the nutritional status of the community. WHO Monograph No. 53. Geneva.

17. Tee, E. S., Mohd. Ismail, N., Mohd. Nasir, A. and Khatijah, I., "Nutrient Composition of Malaysian Foods", 4th edition, Malaysian Food Composition Database Program, Institute for Medical Research, Kuala Lumpur, 1997. 
18. Malaysian Dietary Guidelines, National Coordinating Committee on Food and Nutrition, Ministry of Health, Malaysia, 2010.

19. Recommended Nutrient Intakes for Malaysia, A Report on the Technical Working Group on Nutritional Guidelines, National Coordinating Committee on Food and Nutrition, Ministry of Health, Malaysia, 2015.

20. Shashikala, S., Kandiah, M., Zalilah, M.S., Khor, G.L., 2005. Nutritional status of 1-3year-old child and maternal care behaviors in the Orang Asli Malaysia. S Afr J Clin Nutr., 18: 173-80.

21. Hayati, M.Y., Ching, T.S., Roshita, I, and Safiih, L., 2007. Anthropometric indices and lifestyle practices of the indigenous (Orang Asli) adults in Lembah Belum, Grik of Peninsular Malaysia. Asia Pac J Clin Nutr., 16 (1): 49-55.

22. Haemamalar, K., Zalilah, M.S. and Neng, A.A., 2010. Nutritional status of Orang Asli (Che Wong tribe) adults in Krau Wildlife Reserve, Pahang. Mal J Nutr., 6(1): 55-68.

23. Chua, E.Y., Zalilah, M.S., Chin, Y.S. and Norhasmah, S., 2012. Dietary diversity is associated with nutritional status of Orang Asli children in Krau Wildlife Reserve, Pahang. Mal J Nutr., 18(1): 1-13.

24. WHO and UNICEF. 2009. "WHO Child Growth Standards and the Identification of Severe Acute Malnutrition in Infants and Children. A Joint Statement by the World Health Organization and the United Nations Children's Fund." http://www.who.int/nutrition/publication s/severemalnutrition/9789241598163/ en/.

25. United Nations Children's Fund, World Health Organization, The World Bank. UNICEFWHO- World Bank Joint Child Malnutrition Estimates. (UNICEF, New York; WHO, Geneva; The World Bank, Washington, DC; 2012)

26. WHO, 1999. Nutrition for health and development. Geneva.

27. UNICEF global databases, 2016, based on MICS, DHS and other nationally representative sources. Data included in these global averages are the most recent for each country between 2010-2016
28. Nargis Masroor, Jamaluddin Ab Rahman, Tin Myo Han, Muzzaffar Ali Khan Khattak and Aye Aye. Factors Affecting Nutritional Status of Children below 24 Months in Pekan District, Pahang, Malaysia. Mal J Nutr 20(2): 197 - 207, 2014.

29. Khor, G.L. and Shariff, Z.M., 2008. The ecology of health and nutrition of "Orang Asli"(Indigenous people) women and children in peninsular Malaysia. Tribes and Tribals (Special Volume), 2: 67-778.

30. Naser, I. A., Jalil, R., Muda, W., Manan, W., Nik, W., Suriati, W. and Abdullah, M.R. (2014). Association between household food insecurity and nutritional outcomes among children in Northeastern of Peninsular Malaysia. Nutrition Research and Practice, 8.

31. WHO, 2008. Action plan for the global strategy for the prevention and control of non-communicable diseases, 2008-2013. Geneva, World Health Organization (WHO).

32. United Nations Development Programme (UNDP), 2006. UNDP and indigenous peoples: A policy of engagement (access on December 12, 2006 at (http://www.undp.org/poverty/docs.civils ociety/IP Policy English.pdf)

33. Cahill, G. F. Fuel metabolism in starvation. Annu. Rev. Nutr. 26, 1-22 (2006)

34. Myatt M, Duffield A, Seal A, et al. (2009) The effect of body shape on weight-forheight and mid-upper arm circumference based case definitions of acute malnutrition in Ethiopian children. Ann. Hum. Biol. 36, 5-20.

35. Sinha R, Kapoor S, Kapoor AK (2008). Tracing the response of subcutaneous fat accumulation in two generations of males. HOMO - J. Comp. Hum. Bio. 59: 429-438.

36. Addo OY, Himes JH. Reference curves for triceps and subscapular skinfold thicknesses in US children and adolescents. Am. J. Clin. Nutr. 2010; 91:635-642.

37. Wells JCK. The evolutionary biology of human body fatness: thrift and control. Cambridge: Cambridge University Press; 2010.

38. Lohman TG, Going SB. Body composition assessment for development of an 
international growth standard for preadolescent and adolescent children. Food Nutr Bull. 2006;27: S314-S325.

39. Sen J, Mondal N. Fat mass and fat-free mass as indicators of body composition among Bengalee Muslim children. Ann Hum Biol. 2013; 40:286-293.

40. Thibault R, Pichard C. The evaluation of body composition: a useful tool for clinical practice. Ann Nutr Metab. 2012; 60:6-16

41. Waterlow JC. Classification and definition of protein calorie malnutrition. BMJ 1972;3:566-9.

42. Chen LC, Chowdhury MK, Huffman SL. Anthropometric assessment of energy protein malnutrition and subsequent risk of mortality among preschool children. $A m \mathrm{~J}$ Clin Nutr 1980;33:1836-45.

43. Vitamin A Supplementation: A decade of progress (c) The United Nations Children's Fund (UNICEF), 2007

44. Oral Health Division, Ministry of Health Malaysia. Dental Epidemiological Survey of Pre-school Children in Malaysia 1995

45. Oral Health Division, Ministry of Health Malaysia. National Oral Health Survey of Preschool Children 2005 (NOHPS 2005)

46. AK Norimah, HC Koo, SY Tan, et al. Whole grain intakes in the diets of Malaysian children and adolescents-findings from the MyBreakfast Study. PloS one 10 (10), e0138247

47. J Mohamed HJ, L SL, M Taib MN, A Karim $\mathrm{N}$, et al. Characteristics associated with the consumption of malted drinks among Malaysian primary school children: findings from the MyBreakfast study. BMC Public Health 15 (1), 1322

48. ES Tee, AR Nurliyana, AK Norimah, et al. Breakfast consumption among Malaysian primary and secondary school children and relationship with body weight statusFindings from the MyBreakfast Study. Asia Pacific journal of clinical nutrition 27 (2)

49. Mohd Taib Mohd Nasir, Abdul Razak Nurliyana, A. Karim Norimah, et al. Consumption of ready-to-eat cereals (RTEC) among Malaysian children and association with socio-demographics and nutrient intakes - findings from the MyBreakfast Study CNEST. Food \& Nutrition Research 61 (1)

50. Ditmyer M, Dounis G, Mobley C, Schwarz E: A case-control study of determinants for high and low dental caries prevalence in Nevada youth. BMC Oral Health. 2010, 10: 24-10.1186/1472-6831-10-24.

51. WHO, UNICEF. \& ICCIDD, 2007. Assessment of iodine deficiency disorders and monitoring their elimination. 3rd Ed. Geneva: World Health Organization

52. Ismail MN, Norimah AK, Ruzita AT, et al. (2003) Nutritional Status and Dietary Habits of Primary School Children in Peninsular Malaysia. Final Report for UKMNestle Research Project. Kuala Lumpur: Universiti Kebangsaan Malaysia

53. Poh BK, Kathryn Tham BL, Wong SN, Winnie Chee SS, Tee ES. Nutritional status, dietary intake patterns and nutrition knowledge of children aged 5-6 years attending kindergartens in the Klang Valley, Malaysia. Malays J Nutr 2012; 18:231-42. 